\title{
Pelatihan desain busana berbasis Adobe Photoshop
}

\author{
Hamidah Suryani ${ }^{1}$, Irmayanti ${ }^{2}$, Kurniati $^{3}$ \\ ${ }^{1,2,3}$ Fakultas Teknik, Universitas Negeri Makassar
}

\begin{abstract}
The partner of this Community Partnership Stimulus Program (PKMS) was The teachers fashion city of Makassar. The problem is lack of knowledge and skills of the teachers and based in design and adobe photoshop.Methods used is: lectures, demonstration, discussion, demonstration and practices directly.Achieved results is ( 1 ) partners have knowledge with design and use application adobe phtoshop, ( 2 ) participants in the jump join the is characterized by the number of participants accordance with the target planned.
\end{abstract}

Keywords: training, fashion design, Adobe Photoshop

\section{PENDAHULUAN}

Perkembangan penggunaan teknologi komputer terus meningkat seiring dengan meningkatnya kebutuhan manusia, tanpa terkecuali dalam bidang fashion. Teknologi komputer merupakan satu dari sekian banyak hal yang dibutuhkan dalam perkembangan bisnis di dunia tanpa terkecuali Indonesia, bahkan kita dapat menyebutnya sebagai faktor pokok bagi perkembangan dunia bisnis saat ini. Dunia bisnis di bidang busana telah terpengaruh dan mengalami perkembangan secara progresif dalam mempergunakan teknologi komputer untuk membantu proses pembuatan desain busana hingga ke tahap pembuatan busana. Lebih jauh lagi, penggunaan komputer dalam mendesain busana merupakan suatu jaringan perangkat teknologi yang berkemampuan tinggi dan serba bisa, sehingga seorang desainer yang telah menguasai teknologi komputer dalam proses pendesainan busana, pada umumnya akan mampu menghasilkan dan mewujudkan ide-ide secara lebih cepat dibandingkan bila dikerjakan dengan cara yang lainnya. Hal ini sangat mendukung dalam mewujudkan target produksi dan efisiensi yang harus dipenuhi oleh suatu industri garmen.

Dengan adanya perkembangan teknologi komputer di bidang industri busana hal tersebut, memberi dampak pada dunia pendidikan. Pendidikan merupakan sebuah sarana yang efektif dalam mendukung perkembangan serta peningkatan sumber daya manusia menuju ke arah yang lebih positif (Budiana, 2015). Sekolah Menengah Kejuruan (SMK) merupakan salah satu bentuk lembaga pendidikan formal yang dituntut mampu mengikuti perkembangan teknologi sehingga menghasilkan lulusan yang kompeten secara kognitif, psikomotorik, dan afektif. Pengenalan teknologi baru harus dilakukan dalam proses kegiatan belajar mengajar di SMK agar peserta didik mampu menjadi kader yang siap dalam menghadapi tantangan dunia di era teknologi. Menurut Suryanto (2012) mengatakan bahwa upaya untuk menghasilkan tamatan SMK yang sesuai dengan kebutuhan dunia usaha (DU) dan dunia industri (DI), yang secara nyata terus berkembang dari waktu ke waktu, maka kurikulum SMK juga harus dirancang dan dilaksanakan untuk menyesuaikan dengan kompetensi dan keadaan yang sedang berkembang, khususnya di era teknologi dan pasar bebas.

Permasalahan yang muncul seiring dengan dirancangnya kurikulum SMK yang mengikuti perkembangan teknologi adalah faktor penguasaan teknologi oleh para guru. Sebagaimana kita ketahui, dalam pendidikan di sekolah, guru adalah motor utama penggerak dalam pelaksanaan pembelajaran. Salah satu mata pelajaran yang menggunakan program komputer pada SMK program keahlian Tata Busana yang mata pelajaran Desain Busana yang mengharuskan peserta didik menggunakan aplikasi komputer. Oleh karena itu penggunaan komputer oleh guru sudah 
menjadi keharusan dalam rangka meningkatkan profesionalisme guru Tata Busana.

Kurangnya penguasaan pengetahuan dan keterampilan dalam mendesain busana berbasis teknologi komputer di kalangan guru khususnya kelompok guru yang tergabung dalam Majelis Musyawarah Mata Pelajaran (MGMP) Tata Busana di Kota Makassar menjadi masalah besar yang harus dicarikan solusi. Gambaran nyata dari permasalahan yang dihadapi oleh guru Tata Busana di Kota Makassar, dimana pada saat survey awal terlihat bahwa para guru mengalami kesulitan dalam menerapkan teknologi komputer dalam proses pembelajaran desain busana di sekolah, hal ini dikarenakan kurangnya pengetahuan dan keterampilan guru.

Salah satu usaha yang dapat menjawab permasalahan di atas yaitu pemberdayaan masyarakat melalui Program Kemitraan Masyarakat Stimulus (PKMS) adalah pelatihan. Pelatihan mendesain busana berbasis Adobe Photoshop merupakan bagian dari kegiatan yang bermaksud memberikan pengetahuan dan teknologi bagi para guru tata busana. Menurut Dewi (2012) bahwa Aplikasi Adobe Photoshop pada dasarnya merupakan aplikasi pengolah gambar, namun seringkali pula ia digunakan untuk mengubah tampilan suatu objek, misalnya teks atau tulisan. Adobe Photoshop bukan pengolah kata, tapi ia dapat membuat beragam efek menarik untuk mempercantik tampilan gambar dan teks. Penggunaan aplikasi Adobe Photoshop dalam merancang busana dapat bereksplorasi dalam menemukan inovasi-inovasi desain yang baru.

Guru Tata Busana harus memiliki pengetahuan dan keterampilan dalam mendesain busana berbasis Adobe Photoshop karena kompetensi tersebut merupakan bagian dari mata pelajaran desain busana yang semakin hari semakin mengalami perkembangan. Desain busana dengan menggunakan apliksi Adobe Photoshop yang telah banyak diterapkan di dunia industri, menjadi salah satu materi bahan ajar bagi peserta didik pada program keahlian Tata Busana agar dapat berkembang memenuhi tuntutan di dunia industri.

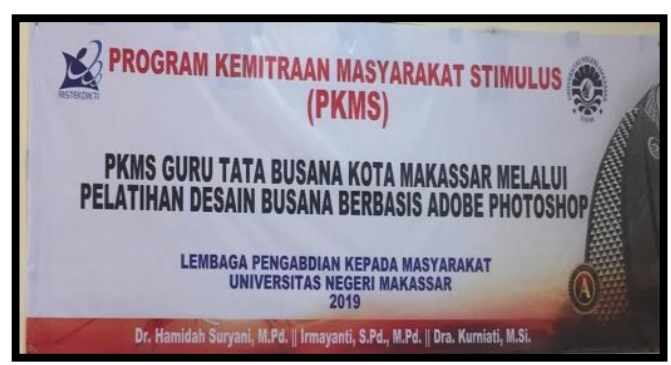

Gambar 1. Spanduk Kegiatan PKMS

\section{METODE PELAKSANAAN}

Metode yang digunakan dalam pelaksanaan pelatihan desain busana berbasis Adobe Photoshop bagi kelompok guru Tata Busana di Kota Makassar sebagai berikut.

1. Tahapan pemberian materi dengan metode ceramah

Materi yang disajikan terkait dengan mendesain busana dengan menggunakan aplikasi Adobe Photoshop meliputi pengertian Adobe Photoshop, mengoperasikan Adobe Photoshop CS5, halaman kerja Adobe Photoshop, mendesain motif tekstil dengan dilengkapi color window dan color way, dan pewarnaan desain sketsa dan layouting.

\section{Tahapan Demonstrasi}

Tahapan ini dilaksanakan dalam bentuk pelatihan dan praktek langsung untuk mempraktekkan langkah-langkah kerja dalam penggunaan perangkat yang ada dalam Adobe Photoshop, halaman kerja Adobe Photoshop, mendesain motif tekstil dengan dilengkapi color window dan color way, dan pewarnaan desain sketsa dan layouting.

3. Tahapan Pendampingan kepada para peserta pelatihan, dalam rangka:

a. Pemahaman dan aplikasi pengetahuan dan ketrampilan mendesain busana menggunakan Aplikasi Adobe Photoshop.

b. Merancang busana yang kreatif, dan inovatif dengan memanfaatkan Aplikasi Adobe Photoshop (mulai dari mendesain motif tekstil, drapping fashion sampai pada pewarnaan desain sketsa dan layouting). 


\section{HASIL DAN PEMBAHASAN}

Implementasi pelaksanaan kegiatan Program Kemitraan Masyarakat Stimulus (PKMS) melalui pelatihan desain busana berbasis Adobe Photoshop yaitu meliputi tahapan pemberian materi dan diskusi, demonstrasi/praktek, dan pendampingan mitra berlangsung sesuai dengan tahap pelaksanaan yang telah direncanakan.

Kegiatan Program Kemitraan Masyarakat dalam rangka pemberdayaan kelompok guru Tata Busana di Kota Makassar melalui pelatihan desain busana berbasis Adobe Photoshop dilaksanakan pada hari Senin, 27 Mei 2018 dan hari Selasa, 28 Mei 2019, di SMKN 8 Makassar. Narasumber kegiatan terdiri dari 3 orang dosen yang dibantu oleh 2 orang mahasiswa sebagai panitia sekaligus sebagai asisten pelatihan. Modul yang digunakan dalam sesi pelatihan ini berupa modul Aplikasi Komputer Terapan Busana. Total jumlah peserta adalah 12 orang yang terdiri dari 4 peserta pelatihan dari SMKN 6 Makassar dan 8 peserta pelatihan dari SMKN 8 Makassar.

\section{A. Pemberian Materi}

Pelatihan diawali dengan mentransfer pengetahuan kepada peserta pelatihan mengenai program Adobe Photoshop yang terdiri pengenalan bagian-bagian dari jendela Adobe Photoshop, menu bar, panel option dan tools box. Dilakukan juga diskusi dua arah sehingga peserta dapat lebih faham mengenai materi yang disampaikan (Gambar 2).

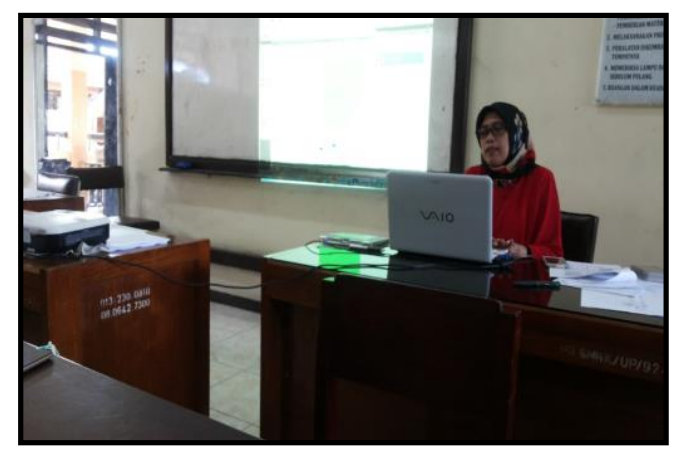

Gambar 2. Pemberian materi pengenalan aplikasi Adobe Photoshop

\section{B. Demonstrasi/Praktek}

Tahap ini merupakan tahapan penting dalam pelaksanaan PKMS yang dimulai dengan praktek langsung untuk mempraktekkan langkah-langkah kerja dalam penggunaan perangkat yang ada dalam Adobe Photoshop, halaman kerja Adobe Photoshop, mendesain motif tekstil dengan dilengkapi color window dan color way, dan pewarnaan desain sketsa dan layouting.

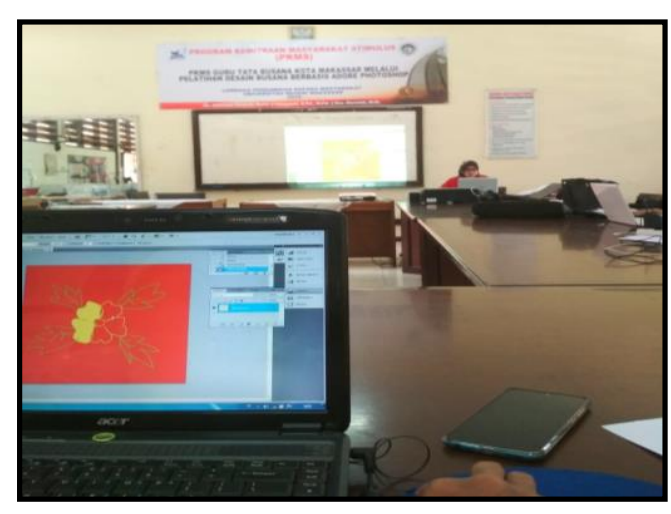

Gambar 3. Praktek langsung membuat desain motif

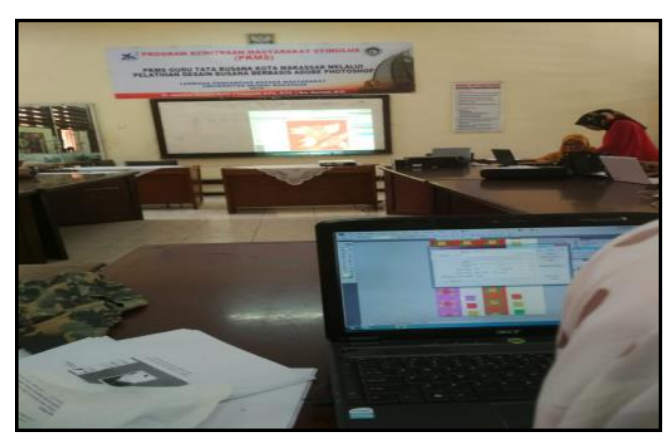

Gambar 4. Praktek langsung membuat color window dan color way

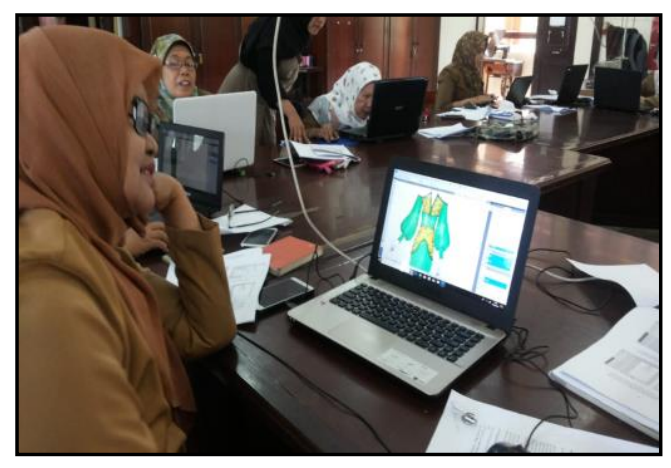

Gambar 5. Praktek langsung mendesain sketsa dengan Adobe Photoshop 
Ketercapaian hasil pelaksanaan kegiatan Program Kemitraan Masyarakat Stimulus (PKMS) pada kelompok guru Tata Busana di Kota Makassar dengan memberikan pembelajaran dan pendampingan dalam meningkatkan pengetahuan dan keterampilan mendesaian busana berbasis Adobe Photoshop ini ditandai dengan mengidentifikasi melalui indikator keberhasil kegiatan yang mencakup ketercapaian tujuan kegiatan, target kegiatan, dan manfaat kegiatan. Adapun ketercapaian hasil kegiatan sebagai berikut.

\section{Tercapaianya Tujuan}

Selama berlangsungnya pengabdian, peserta sangat antusias berpartisipasi dalam pelaksanaan pelatihan yang dilakukan oleh tim pelaksana dari awal sampai berakhirnya kegiatan pelatihan.

\section{Tercapainya Target}

Target tercapainya kegiatan masyarakat ini, melalui pelatihan desain busana berbasis Adobe Photoshop telah tercapai dapat ditunjukkan dengan partisipasi peserta pelatihan yang telah memiliki pengetahuan dan keterampilan dalam mendesain busana menggunakan aplikasi Adobe Photoshop.

Untuk mengidentifikasi keberhasilan tersebut, maka dilakukan evaluasi melalui dua cara yaitu memberikan kuesioner di awal dan di akhir kegiatan untuk menilai tingkat pengetahuan dan keterampilan peserta pelatihan dalam praktik mendesain busana dengan menggunakan aplikasi Adobe Photoshop.

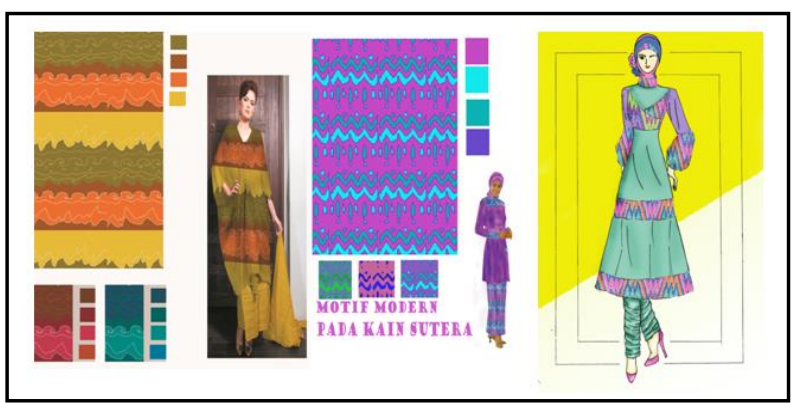

Gambar 6. Hasil karya peserta pelatihan mendesain busana berbasis Adobe Photoshop

\section{Tercapainya Manfaat}

Pelaksanaan kegiatan pengabdian masyarakat dengan pelatihan desain busana berbasis Adobe
Photoshop memberikan manfaat yang signifikan pada peningkatan pengetahuan dan keterampilan dalam mendesain busana menggunakan aplikasi Adobe Photoshop.

\section{KESIMPULAN}

Hasil pelaksanaan kegiatan Program Kemitraan Masyarakat Stimulus (PKMS) melalui "Kelompok guru Tata Busana melalui Pelatihan Desain Busana Berbasis Adobe Photoshop" dapat meningkatkan pengetahuan dan keterampilan dalam mendesain busana dengan menggunakan aplikasi Adobe Photoshop yang menjadi salah satu alternatif dalam menghasilkan suatu karya desain yang kreatif dan inovatif sehingga guru-guru memiliki kompetensi dalam mengajarkan desain busana. Hasil pelatihan ini diharapkan dapat menghasilkan lulusan SMK yang lebih profesional di bidang Tata Busana.

\section{UCAPAN TERIMA KASIH}

Ucapan terima kasih dan penghargaan setinggitingginya atas segala bantuan material dan moril pengabdi sampaikan pada masing-masing kepada: (1) Rektor Universitas Negeri Makassar melalui dana PNBP, (2) Ketua Lembaga Penelitian dan Pengabdian Masyarakat (LP2M) UNM melakukan monitoring, dan meng-evaluasi kegiatan PKMS hingga selesai, (3) MGMP Tata Busana Kota Makassar sebagai peserta pelatihan, dan (4) Kepala sekolah SMKN 8 Makassar yang telah menyediakan tempat pelatihan.

\section{DAFTAR PUSTAKA}

Budiana, H.R., Sjafirah, N.A. dan Bakti, I. (2015). Pemanfaatan Teknologi Informasi Dan Komunikasi Dalam Pembelajaran Bagi Para Guru Smpn 2 Kawali Desa Citeureup Kabupaten Ciamis. Dharmakarya: Jurnal Aplikasi Ipteks untuk Masyarakat. 4(1) 59-62.

Dewi, Mega Sivia. (2012). Penggunaan Aplikasi Adobe Photoshop Dalam Meningkatkan Keterampilan Editing Foto Bagi Anak Tunarungu. E-Jupekhu: Jurnal Ilmiah Pendidikan Khusus. 1(2) $260-270$.

Suryanto, Fajar. (2012). Pelaksanaan Pembelajaran Praktek Produktif Di Sekolah Menengah Kejuruan. Jurnal Penelitian Ilmu Pendidikan, 5 (2), 15-23. 